\title{
Introduction
}

\section{Trauma as cultural palimpsests (post)communism against the background of comparative modernities, totalitarianisms, and (post)coloniality: Introduction}

\begin{abstract}
And then death became a man who will kill me on order. A very young, unassuming man ... an artist of life who takes a shot of vodka beforehand, and after buys a bag of cherries at the market for himself, his wife and his kid. ... I was buying cherries against his cherries.... The rivalry of cherries ended ten years ago. ... but eating cherries got so deep into me that I cannot get rid of it ${ }^{1}$.
\end{abstract}

Herta Müller, Immer derselbe Schnee und immer derselbe Onkel

* Address: Institute of English Studies, ul. Kuźnicza 22, 50-138 Wrocław; Institute of Slavic Studies, ul. Pocztowa 9, 53-313 Wrocław.E-mail: dorota.kolodziejczyk@uwr.edu.pl, mateusz.swietlicki@ uwr.edu.pl.

** Address: Facultatea de Limbi şi Literaturi Străine, Str. Edgar Quinet 5-7 Sector 1, 70106, Bucharest, Romania. E-mail: stefbogdan@gmail.com.

1 Trans. here and in further quotations by Dorota Kołodziejczyk. All quotes come from H. Müller, Mein Vaterland war ein Apfelkern, München 2014 (electronic edition) and H. Müller, Immer derselbe Schnee und immer derselbe Onkel, München 2011 (electronic edition). 
Herta Müller in her life-writing prose shares her memory of fear at the threats of annihilation the Romanian state made against her. Eating cherries is a way of coping that she developed almost unconsciously to create some kind of a deterrent action that has much in common with the ways the author employed as a child to turn into one with nature. At the core of both childhood and adult ways of coping is a desire for a metamorphosis to get free from a feeling of estrangement so tangible as "body itself" (Mein Vaterland war ein Apfelkern). A child eating plants to turn into them and be one with powerful nature grows into an adult trapped in a totalitarian state, eating cherries to defy a Securitate executioner's eating of cherries on the way to do away with her - these are structurally and emotionally akin strategies rooted in childhood magical thinking geared to acquire the sense of agency and self. Replacing the reality lacking these necessary foundations of life is the chief purpose of a ritual which enables magic that, in turn, psychoanalysis knows under the name of childhood narcissism. This is narcissism of a special kind: instead of promising imaginary omnipotence, it presupposes merely, or no less than, survival, and is enacted as literally enduring time. (Immer derselbe Schnee und immer derselbe Onkel)

Herta Müller's accounts of her traumatic experience of the totalitarian state are by all means exemplary of thinking about traumas of post-Second World War societies in the Eastern bloc. The reader will find there a whole catalogue of typical symptoms, if anything can be typical of trauma: pervasive silences; the aura of inarticulate mystery surrounding families and sensed acutely by children whose adult comprehension comes with the childhood memory of puzzled fear; objects that bear witness to unspoken past events; threats from the state whose uncanny familiarity again reminds of the unspoken stories from childhood and suggests that postmemory is transferred less through words and more through the body, the raw sensation of fear and realization of helplessness at the hands of all-powerful state; and, last but not least, the minority status whose role of a scapegoat for the vagaries of communist nationalism only exacerbates the sense of individual's meaninglessness in the grip of all-controlling state.

But these are compulsive repetitive behaviours Herta Müller writes about that constitute the core of traumas induced by the communist state. Recounting her mother's persistent housework, especially cleaning, Müller wonders if this is not the effect of her mother's imprisonment in a Soviet work camp for five years after the Second World War:

For my mother work was something mechanical, it was part of her nature. Mother did not get tired when she worked, she was both totally absent and fully present. Because she was absent to herself, she was becoming what she did with her hands. She disappeared as a person and became a motor, a process in a dress and apron. (Mein Vaterland war ein Apfelkern)

Years after, when Herta Müller works briefly as kindergarten teacher, she faces again the riddle of that repetition which may be a return to the supressed trauma as much as it can be a way of derailing it from the tracks of memory or, even, a way of 
defying the core of trauma, the infliction of pain itself. Kindergarten children both fear being beaten, which, Müller remembers, she discovers as the chief educating method in that institution, and beg to be beaten. Their repertoire of communication is limited to the reactive force of being beaten: "They despised me, because I did not beat them. They required beating, as if it were a gift, grace. They did not react to words or shouting" (Mein Vaterland war ein Apfelkern). For Müller this is a miniature replica of the totalitarian state, and, at the same time, its perfectly logical consequence: "I think that everything was connected, without the image of the man of concrete and ideology that choked everything there would be no bats at kindergarten" (Mein Vaterland war ein Apfelkern).

Cathy Caruth in her reading of Freud's theory of trauma offers a reconsideration of the repetition compulsion central for trauma theory, and observes that it is not exactly the return and overcoming narrative in which the child in Freud's study engages in his "fort und da" play, but a creation of a new language "from beyond the story". ${ }^{2}$ If we follow this proposition, the repetitive behaviours that Müller recounts in her writing are indeed not so much ways of working through trauma by way of reliving it, but, rather, the means of doing away with oneself as memory of one's presence in an event that could have been fatal. Compulsive repetitions are the same category of deterrent actions as childhood plant-eating or adult cherry-eating - deferrals of the self through hanging the time up in order to endure.

The obsessive-compulsive behaviours, like the villagers' tenacity with work, especially her mother's incessant cleaning, and, by extension, the repetitive absurdities of the totalitarian state where lining up for milk or bread may be as much a way to fight against state-induced hunger as it may be a repeated facing the trauma of having nothing under control, not even the basic conditions of sustenance, necessitate the question of memory, remembering, recounting and making sense. In brief, the persuasive aspect of trauma narrative, that is usually imperfect, full of gaps, omissions, perhaps even fake memories, undeciphered signals, and all kinds of beatingaround-the-bush strategies of evasion, is what a trauma researcher has to confront. Most of all, s/he has to confront the most notorious effect of trauma that is not even the memory of pain, but the threat of the disappearance of memory as the only trace of what happened in the past, and, with it, of what makes the human self - of remembering as a combined effect of emotions and social bonding of words. This is the threat of ultimate silence and emptiness that trauma brings about: "I think that there was something at least a tad false everywhere in this village. What stood there as always, as its depressingly empty three hundred years, had in reality been long turned upside down by the catastrophes of history" (Mein Vaterland war ein Apfelkern).

The discourse of trauma has been taken by some to be the result of a transformation of the actual content (the "reality" which caused the trauma) by disguising, displacing, condensing, eliding, etc. very much like the Traumarbeit proposed

2 C. Caruth, "Parting Words: Trauma, silence and survival", Cultural Values 2001, vol. 5. 
by Freud or like the aesthetic procedures of stylization and literaturization. ${ }^{3}$ Such critical views suggest that the recording of traumatic events starts from an original factual truth which is then encoded and communicated in a more or less contrived manner. This is consistent both with an ancient rhetorical tradition which claims that the orator's style is meant to masterfully clothe the factual or ideational body and with the psychoanalytical model whereby the "latent" content is transfigured into the "manifest" representation (Freud) or the "real" into the "symbolic" (Lacan). According to this model, trauma is a stratified palimpsest and the interpreter is expected to perform a procedure similar to the therapeutic anamnesis in order to shed the crafty coating and dispel the superficial layer.

From a postmodernist perspective, which aligns itself to an alternative rhetorical tradition whereby matter and verbal form are inseparable, one cannot extract a supposedly empirical reality of trauma from its inextricable discursive - and therefore subjective-embedding. Traumatic content is perceived, selected, and evaluated as such by the consciousness of the victims/witnesses precisely because it is abhorrent and hurtful to their subjectivity. Reality is recorded as trauma and trauma is the only reality for the ailing subject. Or, as feminist critic Leigh Gilmore bluntly puts it: "without language, experience is nothing". ${ }^{4}$ In contrast with the stratified palimpsest model, this understanding of trauma discourse posits that our traumatic experiences (re)present themselves to our subjectivity as always already translated into a discursive version. As such, the trope of the palimpsest turns from a metaphor into a paradox: trauma is no longer a stratification of successive layers but a coplanar palimpsest where objective facts and their subjective recording coexist at the same discursive level, very much like the original and the translation are coplanar for Walter Benjamin (Die Aufgabe des Übersetzers). Trauma is the simultaneous repression and re-presentation (i.e., imaging and re-visiting) of the shattering experience (a "coincidence of trauma and self-representation"5). Let us call this the Traumaarbeit, that is, the discursive process wherein the traumatic "facts" are made consubstantial with their subjective re-presentation. Traumaarbeit consists of symbolic (trans)formations that equally show and camouflage the cause, the object, and the nature of the victim's distress. The actual suffering is inscribed from the beginning in its transformational version and the two present themselves to our understanding like two different things merged into one and the same anamorphic image. Similar coplanar existence may be attributed to private and collective or to past and present traumas,

3 Unlike the more earnest "testimonials" of simple folk, most Romanian communist detention memoirs by the intellectual elite are seen as less reliable and less "truthful" because they are allegedly the result of a literaturization process. The view is shared not only by literary critics such as Adrian Marino (who had first-hand experience of communist imprisonment) and Ruxandra Cesereanu, but also by a good many memorialists themselves: psychologist Nicolae Mărgineanu, journalist Gabriel Bălănescu, diplomat Constantin Cesianu, writer and politician Ioan Victor Pica, or historian Constantin C. Giurescu.

${ }^{4}$ L. Gilmore, The Limits of Autobiography: Trauma and Testimony, Ithaca 2001, p. 6.

${ }^{5}$ Ibid., p. 3. 
to pre-communist and communist tragedies, or, as Marianne Hirsch has claimed, to first hand and "postmemory", or to historical continuity and rupture. ${ }^{6}$

The essays gathered in this volume tackle both the individual and social effects of traumas inflicted by the totalitarian communist state. The assessment of the totalitarian past has been the object of divisive and partial political debates, themselves, at times, no more than post-traumatic symptoms at the discursive level. Our volume investigates the seriality and simultaneity of trauma in the recent history of Central and Eastern Europe that spans a tragically wide spectrum from ghettos to gulags to globalization, from Holocaust to communist and postcommunist mass killings, from concentration camps to immigration camps, as well as the palimpsestic interplay between the different historical and experiential layers of cultural distress.

\section{Bibliography}

Caruth, C. 2001. "Parting Words: Trauma, silence and survival." Cultural Values. vol. 5.

Gilmore, L. 2001. The Limits of Autobiography: Trauma and Testimony. Ithaca: Cornell University Press.

Hirsch, M. 2012. The Generation of Postmemory: Writing and Visual Culture after the Holocaust. New York: Columbia University Press.

Müller, H. 2011. Immer derselbe Schnee und immer derselbe Onkel. München: Carl Hanser Verlag.

Müller, H. 2014. Mein Vaterland war ein Apfelkern. München: Carl Hanser Verlag.

${ }^{6}$ M. Hirsch, The Generation of Postmemory: Writing and Visual Culture After the Holocaust, New York 2012, p. 5 and passim. 